\title{
RHETORICAL STRATEGIES BY GOVERNOR CANDIDATES \\ IN THE JAKARTA ELECTORAL DEBATE 2017
}

AN ARTICLE

\section{Submitted in Partial Fulfillment of the Requirements \\ for the Degree of Sarjana Sastra}

By:

SUWANDONADI SIMANULLANG

Registration Number: 2131220019

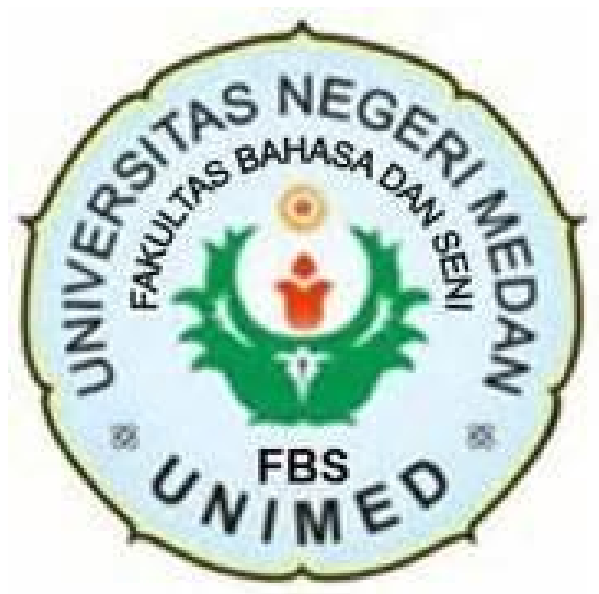

ENGLISH AND LITERATURE DEPARTMENT

FACULTY OF LANGUAGE AND ART STATE UNIVERSITY OF MEDAN 2018 


\section{ARTIKEL \\ RHETORICAL STRATEGIES BY GOVERNOR CANDIDATES IN THE JAKARTA ELECTORAL DEBATE 2017}

Disusun dan Diajukan oleh:

Suwandonadi Simanullang

NIM. 2131220019

Telah diverifikasi dan dinyatakan memenuhi syarat untuk diunggah pada jurnal online

Medan, Juli 2018

Menyetujui

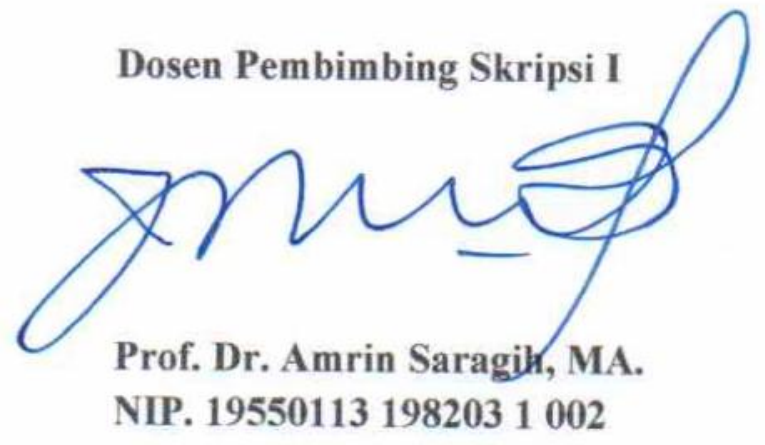

Dosen Pembimbing Skripsi II

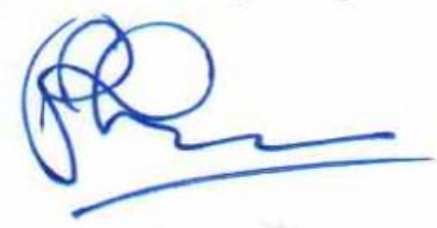

Dr. Rahmad Husein, M.Ed.

NIP. 196206291988031002

Ka. Program Studi

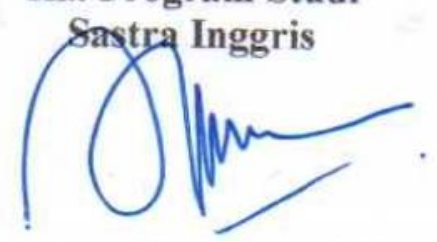

Juli Rachmadani Hasibuan, S.S., M.Hum.

NIP. 198207112008012008 


\title{
RHETORICAL STRATEGIES BY GOVERNOR CANDIDATES IN THE JAKARTA ELECTORAL DEBATE 2017
}

\author{
*Suwandonadi Simanullang \\ **Amrin Saragih \\ **Rahmad Husein
}

\begin{abstract}
Manullang, Suwandonadi. Registration Number: 2131220019. Rhetorical Strategies by Governor Candidates in the Jakarta Electoral Debate 2017. A Thesis. English Literature, Faculty of Language and Art, State University of Medan. 2018.

This study deals with rhetorical strategies used by governor candidates in the Jakarta Electoral Debate 2017. The aims of this study are to (1) describe rhetorical strategies which are used by governor candidates in the Jakarta Electoral Debate 2017, (2) analyze the realizations of rhetorical strategies, (3) reason the use of rhetorical strategies. This study was conducted by using descriptive qualitative research. The source of data was the Jakarta Electoral Debate 2017. The data were collected by using documentary technique. Instrument for collecting the data was the documentary sheet. The results of the study show that the three rhetorical strategies, i.e. Logos, Ethos, Pathos, are found in the debates. The three realizations of rhetorical strategies are also found in the debates. Reasons for using rhetorical strategies are to acclaim, to attack, and to defend.
\end{abstract}

Keywords: Rhetorical Strategies, Governor Candidates, Jakarta Electoral Debate

\footnotetext{
*Graduate

**Lecturer
} 


\section{INTRODUCTION}

\section{Background of the Study}

Aristotle once descibed rhetoric in The Art of Rhetoric as "instrumens of exploring the overall feasible ways to persuade the audience whatever the subject is in relation to" (Fengjia, Jia, \& Yingying, 2016). Therefore, the aims of rhetoric is to influence, impress and persuade the audiences. Rhetorical strategy is one of ways to persuade people about something in order to achieve the rhetorical effects. Rhetorical strategy is very common in many areas, whether Advertising, Literature, Politic, Diplomacy, etc. For example, in the advertising world, advertisers always try to attract public attention by their strategies of rhetoric. Rhetorical devices serve as a tool to lend beauty, variety, vividness, force, and power to the language (Chetia, 2015).

The 2017 Jakarta election was held in Wednesday, 15th of February 2017, when 7.108.589 Jakarta people elected one out of three governor candidates. There were 13.023 voting places (www.kompas.com). The three candidates are Agus Harimurti Yudhoyono and Sylviana Murni, Basuki 'Ahok' Tjahaja Purnama and Djarot Syaiful Hidayat, and Anies Baswedan and Sandiago Uno. The first pair is supported by political parties such as Demokrat, PKB, PAN and PPP. The second pair is supported by PDIP, Golkar, Nasdem and Hanura. While the third

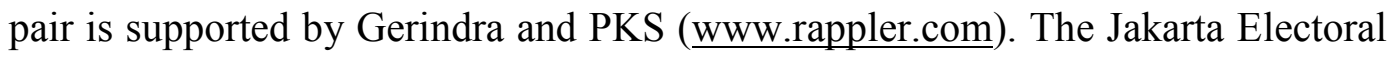
Debate 2017 itself was held in three (3) times, i.e. on 13 January 2017, 27 January 2017 and 10 February 2017. By this debate, the governor candidates, each of them, try to persuade hearers in a persuasiveness. 
There are five part divisions of rhetoric, i.e. invention, arrangement, style, memory, and delivery. This study were focused on one of them, invention, which refers to the development of strategy regarding the means of persuasion. It is beneficial for those readers, practitioners, and even future relevant researchers to understand more and to practice the rhetorical strategies.

\section{REVIEW OF RELATED LITERATURE}

Rhetoric is defined as the art of persuasion. But, the terms of rhetoric and persuasion are still confusing because the two seem very similar. They were focused on how to connect the sender, the message, and the receiver, whether the field they are in. The persuasion itself aims to assure someone to do something appropriate with the speaker's purpose for this moment or the present time (Keraf, 1982: 118). The three modes of persuasion - logos, ethos, pathos - are the rhetorical strategy, some experts say.

Mshvenieradze (2013), states that Logos is persuading by the use of reasoning which includes critical cognition, analytical skill, good memory, and purposeful behavior, which is the most important argumentation. Ethos is the audience perception of the speaker's credibility and authority over the subject s/he is speaking (Murthy \& Ghosal, 2014). Pathos is the mode of artistic persuasion which occurs when the audience is moved through the speech to emotion (Duke, 1990:139). Burgoon and Ruffner (1978:410-419) argue four factors that are influencing persuasiveness of a message regardless of the types of appeal used. 
When the communicator (or speaker or rhetor) has low credibility and the audience does not share his or her views, he or she must often use third-order-data to persuade, which is called evidence. It comes from the third party, a source out of the communicator and the audience (Burgoon and Ruffner, 1978:408). Witte (1994) defines fear appeal as a persuasive message that attempts to arouse the emotion of fear by deficting a personally relevant and significant threat and then follows this description of the threat (Walton, 1996). Gruner (1978), states that "ridicule is the basic component of all humorous material, and ... to understand a piece of humorous material it is necessary only to find out who is ridiculed, how and why" (Martin, 1998). Burgoon and Hufnerr (1978) state that one of ways is to insert qualifiers and the use of metaphors, especially those with sexual or violent connotations.

Benoit (2003), as stated in Isotalus (2011), defines one (out of five) axiom on which his functional theory is founded i.e. Candidates establish preferability through acclaiming, attacking, and defending. Simply, there were three functions for speaker or rhetor or candidate to create impression of preferability i.e. to acclaim, to attack, and/or to defend (Benoit, 2016). Benoit (2016) states acclaim as a proclaim the candidate's strength, attack is identifying the opponent's weaknesses, defense is used to defend themselves from the moderators' questions as well as from attacts by one's opponents. 


\title{
RESEARCH METHODOLOGY
}

\author{
Research Design
}

This study was conducted by using descriptive qualitative research. According to Daymon and Holloway (2002:14), Qualitative research focuses on words rather than numbers, although occasionally numbers are used to indicate the frequency that a theme is found in transcripts or the extent to which a form of action occurs.

\section{Data and Source of Data}

The utterances, exactly the words or clauses consisting rhetorical strategy, by governor candidates, Agus Harimurti Yudhoyono, Basuki Tjahaja Purnama, and Anies Baswedan, in the Jakarta Electoral Debate 2017 were data for this study. The source of data was the Jakarta Electoral Debates 2017.

The Technique of Collecting Data

This study used documentary technique in collecting the data. The documents are three videos of Jakarta Electoral Debates 2017 and its transcripts.

\section{Instrument of Collecting Data}

In order to collect the data, the documentary sheet is used as the instrument to collect the data. 


\section{The Technique of Analyzing Data}

The data were analyzed by using descriptive qualitative techniques. The first was identifying the rhetorical strategies used by the governor candidates in the Jakarta Electoral Debate 2017. The second was Reducing the data which are not relevant. Then, classifying the data and information based on rhetorical strategies. After that, analyzing and interpreting the data which deals with rhetorical strategies used by governor candidates in Jakarta Electoral Debate 2017. Finally, concluding the data which deals with rhetorical strategies used by governor candidates in Jakarta Electoral Debate 2017.

\section{RESEARCH FINDING AND DISCUSSION}

\section{Research Findings}

This study found that the three modes of persuasion or rhetorical strategies are found in the Jakarta Electoral Debate 2017 with totally 431 occurances. Logos is the most dominant used with 208 occurances (48.3\%), followed by Ethos with 115 occurances (35\%), and Pathos with 72 occurances (16.7\%). The four realizations of rhetorical strategies are found in the Jakarta Electoral Debate 2017 with totally 312 occurances. Appeals Varying in Languange Intensity is the most dominant used with 240 occurances (76.9\%), followed by Appeals based on Evidence with 36 occurances (11.5\%), Appeals based on Humor with 22 occurances (7.1\%), and Appeals based on Fear with 14 occurances (4.5\%). The three reasons of using rhetorical strategies are found in the Jakarta Electoral Debate 2017 with totally 431 occurances. Acclaim is the most dominant used with 
252 occurances (58.5\%), followed by Attack with 116 occurances (26.9\%), and Defense with 63 occurances (14.6\%).

\section{Discussions}

Beiner, as cited in Ko (2015), said that the three modes of persuasion namely: Logos, Ethos, and Pathos, which were asserted by Aristotle are essential to achieving persuasion. The findings of this study shows that the three modes of persuasions or rhetorical strategies were practiced by the three Jakarta governor candidates in the debates.

Ko (2015) in his study found that Pathos is the most prevalent strategy used by Taiwan's President, Ma Ying-Jeou, while Ethos is the least one. In contrast to Ko's finding, Alvi \& Baseer (2012) in their study explored that Obama, on his speech, dominantly used Ethos and Pathos while logos is the least one. In contrast to both previous studies, this study found that Logos is the most prevalent used in the debates, followed by Ethos, and Pathos as the least one. The contrastive result between this study and the two previous studies caused by the difference of the arena. In the debate, speaker or rhetor faced a more complex situation. They have to acclaim their positive characteristics, and they also need to attack their opponents while they need to defend themselves from any attack. Benoit (2003), as stated in Isotalus (2011), explaines this about how candidates establish their preferability.

In addition to that of Benoit's explanation, discussing about Policy means comprised of past deeds (record in office), future plans, and general goals. But 
how we could believe candidate's record in office if they do not tell us about anything deals with our rationality or our logical thinking? And how we would impressed about their future plans and general goals if the do not explain us reasons, examples, or anything makes us believe? Candidates should give all about statistics or data and/or facts, reasons, examples, to make audience realize the truth.

According to Burgon \& Huffner (1978), there are four factors in influencing persuasiveness of a message namely: Evidence, Fear, Humor, and Varrying in Language Intensity. The four were used by Jakarta governor candidates in the debates. Varying in Language Intensity were used dominantly, followed by Evidence, Humor, and Fear. Varying in Language Intensity aims to make any word look more intense which is important to arouse the emotion of the audience.

Benoit (2007) suggestion: "candidates tend to use acclaim more than attacks and defense, and attacks more than defense". Candidates acclaim their positive charateristics to persuade or to make audience believes. Then, attack is used to identify the opponent's weaknesses and defense is used to defend themselves from attacks. The finding of this study similar to Benoit's sugeestion, which shown acclaim as the most common used and defense as the least one. Candidates must be different from other candidates, because it can make them preferable for citizens or audience. That is why candidate must acclaim their positive characteristics more and more. In addition, candidates also need to attack or to show the weaknesses of the opponents, which aims to make them more 
preferable. However, They will also be attacked by opponents, so they need to defend themselves.

\section{CONCLUSION AND SUGGESTION}

\section{Conclusions}

After analyzing the data, conclusions are drawn as the following.

(1) The three modes of persuasion or rhetorical strategies, i.e. Logos, Ethos, Pathos, were used to convince the audience to realize the truth, to show the speaker's credibility and authority over the subject, and to arouse the emotion of the audience. The three should be combined to achieve successful persuasion. Jakarta governor candidates have successfully practiced rhetorical strategies in the Jakarta Electoral Debate 2017. The total number of rhetorical strategies used is 431 .

(2) The four realizations of rhetorical strategies, i.e. Evidence, Fear, Humor, and Varying in Language Intensity, are used to influence the persuasiveness of a message. Those realizations are very important to show the trustworthy of the speaker, to show the speaker sociability, and to arouse the emotion of fear. In the debates, Jakarta governor candidates used them to strengthen the arguments or positions. The total number of realizations found is 312 .

(3) Jakarta governor candidates establish their preferability through acclaiming, attacking, and defending. Candidates dominantly acclaimed their positive characteristics or their policy positions in the debates. They also attacked to 
show the weaknesses of their opponents and defended themselves from all questions or attacks by their opponents.

\section{Suggestions}

In relation to the conclusions, suggestions are staged as the following.

(1) Rhetorical strategies are applicable in our daily life. Using the combination of Logos, Ethos, and Pathos will create a successful persuasion. Students, politicians, advertisers, journalists, or related practitioners, should understand those rhetorical strategies in order to compile their speech, writing, article, or other related in a better way.

(2) There were four important factors in influencsing persuasiveness, i.e. Evidence, Fear, Humor, and Varying in Language Intensity. Practitioners should understand those factors in order to make them trustworthy and sociable, and to arouse specific emotions.

(3) The reasons of using rhetorical strategies, i.e. acclaiming, attacking, and defending, depend on the situation. However, the three reasons are applicable wherever they are practiced in. Practitioners should understand those reasons in order to establish their preferability. The findings or any information in this study are important to understand and to practice, or to conduct any research in the future. 


\section{REFERENCES}

Alkhirbash, A. 2016. A Proposed Framework for Analyzing Aristotle's Three Modes of Persuasion. International Journal of English and Education. Vol. 5, No. 4, pp. 111-117

Alvi, S.D. \& A. Baseer. 2012. Application of Aristotle's Ethos, Pathos, and Logos on Barack Obama's Speech, 'Call to Renewal Keynote Address'. Interdisciplinary Journal of Contemporary Research in Business, Vol. 3, No (5), pp. 593-616

Benoit, W.L. 2016. A Functional Analysis of the 2012 London Mayor Debate. $J$ Mass Communicat Journalism, Vol (6), No (2), pp. 296-300

BPS. 2015. Jumlah Penduduk dan Rasio Jenis Kelamin Menurut Kabupaten/Kota di Provinsi DKI Jakarta 2015. Retrieved from https://jakarta.bps.go.id/linkTabelStatis/view/id/137 on 26 of May 2017

Burgon, M \& M. Ruffner. 1978. Human Communication: A Revision of Approaching Speech/Communication. Florida: Holt, Rinehart and Winston

Chetia, B. 2015. Rhetorical Devices in English Advertisement Texts in Indoa: A Descriptive Study. International Journal of Social Science and Humanity. Vol (5), No (11), pp. 980-984

Daymon, C., I. Holloway. 2002. Qualitative Research Methods in Public Relations and Marketing Communications. London: Routledge

Dresing, Thorsten/Pehl, Thorsten/Schmieder, Christian. 2015. Manua (on) Transcription:Transcription Conventions, Software Guides and Practical Hints for Qualitative Researchers. 3rd English Edition. Marburg. Retrieved from http://www.audiotranskription.de/english/transcriptionracticalguide.htm on 25 of February 2018. 
Drumheller, K. \& G. Armfield. 2013. Obama Transforming: Using Functional Theory to Identify Transformational Leadership. Speaker \& Gavel. Vol (50), No (1), pp. 14-36

Duke, K.R. 1990. The Persuasive Appeal of The Chronicler. London: The Almond Press

Li Fengjie, Ren Jia, Zhang Yingying. 2016. Analysis of Rhetorical Devices in Obama's Political Speeches. Internal Journal of Language and Linguistics. Vol.4, No. (4), pp. 141-146.

Hendrikus D.W. 2009. Retorika: Terampil Berpidato, Berdiskusi, Berargumentasi, Bernegosiasi. (13th Ed). Penerbit Kanisius: Yogyakarta

Iqbal, N. 2013. The Rhetoric of Obama: An Analysis of Rhetoric and Genre Characteristics of President Barack Obama's 2013 Inaugural Address. Thesis. University of Gothenburg: Gothenburg

Isotalus, P. 2011. Analyzing Presidential Debates: Functional Theory and Finnish Political Communication Culture. Nordicom Review. Vol (32), No (1), pp. $32-43$

Johnson, S.L.-----. Debate As a Pedadogical Tool. Essay. University of Alaska Anchorge

Keraf, G. 1982. “Argumentasi dan Narasi”. Jakarta: PT.Gramedia Pustaka.

Ko, H. 2015. Political Persuasion: Adopting Aristotelian Rhetoric in Public Policy Debate Strategies. International Journal of Humanities and Social Science. Vol. 5, No.10, pp. 114-123

Lin C.W. 2011. The Study of Political Languange: A Brief Overview of Recent Research. Chia-Nan Annual Bulletin. Vol.37, pp. 471-485. 
Martin, R.A. 1998. Approaches to the Sense of Humor: An Historical Review. In W. Ruch (Ed.), The Sense of Humor, 15-60. Berlin, New York: Mouton de Gryter

Murthy, D.M.L. \& M. Ghosal. 2014. A Study on Aristotle's Rhetoric. Research of English Language and Literature (RJELAL). Vol. 2, No. 4, pp. 249-255

Mutiah, T. 2013. Gaya Retorika Jokowi dalam Program Debat Kandidat Putaran Kedua Calon Gubernur dan Wakil Gubernur Jakarta di JAK TV. Jurnal Komunikasi. Vol. 4, No. (1), pp 12-17

Mshvenieradze, T. 2013. Logos Ethos and Pathos in Political Discourse. Theory and Practice in Language Studies. Vol. 3, No. 11, pp. 1939-1945

Otieno, T.M. 2015. Linguistic Description of the Rhetoric: Barack Obama's Political Speeches. IOSR Journal of Humanities and Social Sciences. Vol. 20, No.(9), pp. 80-92

Ricky, H. 2014. Perbandingan Retorika Prabowo Subianto dan Joko Widodo dalam Debat Calon Presiden 2014: Studi Kasus Retorika Debat Calon Presiden 2014 Mengenai Pembangunan Ekonomi dan Kesejahteraan Sosial. Thesis. Yogyakarta: Atma Jaya University

Situmorang, M.K.T. 2016. Rhetorical Style in the Headline News of the Daily Kompas. Thesis. Medan: State University of Medan

Tomita, S. 2008. Rhetorical Expressions by Simile in David Copperfield. PALA Proceeding. Retrieved from http://www.pala.ac.uk/ on 6 of February , 2017

Zhu-hui Y. \& Miao Y. 2012. Rhetorical Devices in Dialogues of The Big Bang Theory. Sino-US English Teaching. Vol. 9, No.6, pp. 1220-1229

www.definedterm.com.----. Data Collection Instrument. Article. Retrieved from https://definedterm.com/a/definition/80343 on 25 of February 2018 
www.kompas.com. 2017. Total DPT Pilkada DKI Putaran Kedua Mencapai 7,2 Juta Pemilih. Article. Retrieved from http://megapolitan.kompas.com/read/2017/04/07/06143891/total.dpt.pilk ada.dki.putaran.kedua.mencapai.7.2.juta.pemilih on 24 of May 2017

www.lpmpendapa.com. 2016. Pandangan Masyarakat Mengenai Politik.

Retrieved from http://lpmpendapa.com/2016/04/20/pandanganmasyarakat-mengenai-politik/ on 17 of April 2018

www.pilkada.tempo.co. 2017. Debat Pilkada DKI, Tiga yang Baru Dibanding Debat Sebelumnya. Retrieved from https://pilkada.tempo.co/read/news/2017/01/27/348840324/debat-pilkadadki-tiga-yang-baru-dibanding-debat-sebelumnya on 11 of July 2017

www.rappler.com. 2017. Hasil 'real quick count' Pilkada DKI Jakarta 2017 Putaran Pertama. Article. Retrieved from http://www.rappler.com/indonesia/berita/161321-hasil-quick-countpilkada-jakarta-2017 on 24 of May 2017

www.wikipedia.com. 2017. Candidate. Retrieved from https://en.wikipedia.org/wiki/Candidate on 10 of July 2017

www.wikipedia.com. 2017. Governor. Retrieved from https://en.wikipedia.org/wiki/Governor on 10 of July 2017

www.wikipedia.com. 2017. Strategy. Retrieved from https://en.wikipedia.org/wiki/Strategy on 20 of June 2017 